\title{
Načelo zabrane vraćanja i pristup sustavu azila: dva lica iste kovanice
}

DOI: $10.11567 /$ met.31.3.2

UDK: 341.43

342.7

Izvorni znanstveni rad

Primljeno: 04. 12. 2015.

Prihvaćeno: 03. 03. 2016.

\section{Goranka Lalić Novak}

Pravni fakultet Sveučilišta u Zagrebu

goranka.lalic@pravo.hr

\section{SAŽETAK}

Europska unija, kao i druge zemlje na Balkanskoj ruti migracija, bilježi veliko povećanje broja osoba koje traže azil. Paralelno s povećanjem broja izbjeglica koje pokušavaju ući na teritorij EU-a pooštravaju se mjere za upravljanje migracijama, a pravo na azil na razini država članica sve se restriktivnije tumači. Traženje zaštite od proganjanja postaje razlogom za zatvaranje granica i onemogućivanje pristupa teritoriju i sustavu azila. No pristup sustavu azila prvi je korak u ostvarivanju prava na azil kako je ono zajamčeno međunarodnim, europskim i nacionalnim pravom. Osim omogućivanja pristupa teritoriju i sustavu azila koji implicira obvezu država na prihvaćanje izbjeglica kako bi se u pravičnom i učinkovitom postupku utvrdila potreba za međunarodnom zaštitom, države su dužne poštovati načelo zabrane vraćanja (non-refoulement). Razjašnjavanje povezanosti omogućivanja pristupa sustavu azila i zaštite načela zabrane vraćanja svrha je ovog rada. Analiza u radu izvedena je pravnodogmatskom metodom istraživanja i tumačenja pravnih akata i drugih izvora prava te relevantnih preporuka i dokumenata UNHCR-a. Polazi se od pretpostavke da se bez omogućivanja pristupa teritoriju i sustavu azila ne može poštovati načelo zabrane vraćanja. Osim iz međunarodnoga izbjegličkog prava i doktrinarnih tumačenja to proizlazi i iz prakse Europskog suda za ljudska prava u pogledu zabrane mučenja ili drugoga nečovječnog postupanja ili kažnjavanja zajamčene Konvencijom za zaštitu ljudskih prava i temeljnih sloboda. Zaključuje se da kada razmatraju uvođenje novih mjera za upravljanje migracijskim kretanjima, države moraju uzeti u obzir međunarodne i europske standarde u pogledu zaštite načela zabrane vraćanja.

KLJUČNE RIJEČI: pravo na azil, zabrana vraćanja, pristup teritoriju, Europski sud za ljudska prava 


\section{UVOD}

Europska unija suočila se u 2015. s velikim izbjegličkim kretanjima koja se $\mathrm{u}$ javnom i političkom diskursu često nazivaju »najvećom izbjegličkom krizom od Drugog svjetskog rata «. ${ }^{1}$ I Hrvatska, koja se nalazi na tzv. Balkanskoj ruti migracija, od polovine rujna bilježi velika izbjeglička kretanja preko svog teritorija - do početka prosinca kroz nju je prošlo više od 450.000 izbjeglica.

Najveći je generator izbjegličkih kretanja sukob u Siriji. Prema UNHCRovim podacima iz studenoga 2015. (UNHCR, 2015), više od četiri milijuna Sirijaca izbjeglo je iz zemlje, većina u susjedni Egipat, Irak, Jordan i Libanon (2,1 milijun), 1,9 milijuna sirijskih izbjeglica registrirano je u Turskoj, a više od 26.700 na području sjeverne Afrike.

Veliki izazov za države članice EU-a predstavljaju migracije preko Sredozemnog mora - broj migranata i izbjeglica koji se koriste tom rutom za ulazak u Europu u stalnom je porastu. Tijekom 2014. samo je u Italiju stiglo 170.100 neregularnih migranata, od kojih su većina izbjeglice s ratom zahvaćenih područja poput Sirije, Afganistana i Eritreje. Procjenjuje se da je oko 3280 migranata izgubilo život pokušavajući prijeći Sredozemno more (European Union Agency for Fundamental Rights, 2015).

Paralelno s povećanjem broja izbjeglica koje pokušavaju ući na teritorij EU-a pooštravaju se mjere za upravljanje migracijskim kretanjima, a pravo na azil na razini država članica sve se restriktivnije tumači. Krajem 2015. »tvrđava Europa « više nije samo pojam - vanjske granice EU-a ograđene su zidovima i bodljikavim žicama. Drugim riječima, traženje zaštite od proganjanja postaje razlogom za zatvaranje granica i onemogućivanje pristupa teritoriju i sustavu azila.

Pristup sustavu azila temeljni je preduvjet za oživotvorenje prava na azil u praksi - da bi država u suvremenim migracijskim kretanjima između ostalih imigranata mogla prepoznati osobe kojima je potrebna međunarodna zaštita, nužno je osigurati pristup teritoriju i sustavu azila. $U$ tom smislu pristup sustavu azila prvi je korak u ostvarivanju prava na azil, zajamčenoga međunarodnim, europskim i nacionalnim pravom. Istodobno, pristup teritoriju na kojem bi izbjeglice trebale biti zaštićene od proganjanja i sustavu azila očito je ograničen pravom država na kontrolu ulaska, boravka i protjerivanja stranih državljana na svojem teritoriju. Riječ je o dva suprot-

Dimitris Avramopoulos, povjerenik Europske komisije za migracije i unutarnje poslove. »A European Response to Migration: Showing solidarity and sharing responsibility, Press release, Brussels, 14 August 2015, http://europa.eu/rapid/press-release_SPEECH-15-5498_ en.htm (20.11. 2015.). 
stavljena pravna načela prvorazredne važnosti s dalekosežnim političkim, pravnim i upravnim posljedicama.

Omogućivanje pristupa sustavu azila očito implicira obvezu država na prihvaćanje izbjeglica na svoj teritorij kako bi se u pravičnom i učinkovitom postupku utvrdili njihov status i potreba za međunarodnom zaštitom. U tom smislu pristup teritoriju jedna je od najvažnijih sastavnica prava na pristup sustavu azila. Pristup uključuje i prihvat izbjeglica, odnosno pomoć i osiguravanje zadovoljavanja osnovnih životnih potreba. Istodobno izbjeglice imaju pravo biti zaštićene od vraćanja (refoulement), a načelo zabrane vraćanja (non-refoulement) temeljno je načelo izbjegličkog prava, koje se zbog svoje važnosti smatra dijelom međunarodnoga običajnog prava. To načelo navodi i UN-ova Konvencija o statusu izbjeglica iz 1951. (dalje: Konvencija iz 1951.), ${ }^{2}$ temeljni dokument međunarodnoga izbjegličkog prava.

Razjašnjavanje povezanosti pristupa sustavu azila i zaštite načela zabrane vraćanja svrha je ovog rada. Početna je pretpostavka rada da se bez omogućivanja pristupa teritoriju i sustavu azila ne može poštovati načelo zabrane vraćanja, odnosno da odbijanje pristupa sustavu azila može dovesti do kršenja tog načela. Osim iz međunarodnoga izbjegličkog prava i doktrinarnih tumačenja takav zaključak proizlazi i iz prakse Europskog suda za ljudska prava (dalje: ESLJP) u odnosu na zabranu mučenja ili drugoga nečovječnog postupanja ili kažnjavanja zajamčenu čl.3. Konvencije za zaštitu ljudskih prava i temeljnih sloboda (1950) (dalje: EKLJP).

U prvom dijelu rada analizira se pristup sustavu azila i ukratko prikazuju mjere ograničavanja tog pristupa. U drugom dijelu analiziraju se međunarodni standardi zabrane vraćanja te relevantne odredbe pravne stečevine EU-a o azilu kojima se jamči zaštita načela zabrane vraćanja. U trećemu se analiziraju standardi Vijeća Europe, izvedeni na temelju prakse ESLJP-a, s naglaskom na pristup teritoriju i odgovornost države te prirodu rizika od zlostavljanja. U zadnjem se dijelu donose zaključna razmatranja o povezanosti pristupa sustavu azila i načela zabrane vraćanja.

Analiza u radu izvedena je pravnodogmatskom metodom istraživanja i tumačenja pravnih akata i drugih izvora prava te relevantnih preporuka i dokumenata UNHCR-a.

Konvencija o statusu izbjeglica, UNTS 189, 28. srpnja 1951.; SL SFRJ: MU 15/1960; stupila na snagu 21. travnja 1954. 


\section{PRISTUP SUSTAVU AZILA}

Pristup izbjeglica zaštiti i pomoć od drugih država, kada im takvu zaštitu ne može ili ne želi zajamčiti njihova zemlja podrijetla, temeljni je preduvjet za oživotvorenje međunarodnopravnoga izbjegličkog režima u praksi. Važnost postojanja sustava azila i osiguravanje pristupa postupku azila, u skladu s Konvencijom iz 1951., naglašeni su u više zaključaka i preporuka UNHCR-a. ${ }^{3}$

Pristup teritoriju odnosi se na zabranu odbijanja ulaska izbjeglica i tražitelja azila na granicama bez provođenja postupka utvrđivanja izbjegličkog statusa (UNHCR, 1997). Osoba ima pravo zatražiti azil i ako je neregularno ušla u državu prihvata ili u njoj boravila.

U odnosu na osobe koje su presretnute u pokušaju ulaska na teritorij države, a uzimajući u obzir razlikovanje u međunarodnom pravu onih osoba koje trebaju međunarodnu zaštitu i onih koje može zaštititi njihova zemlja podrijetla, potrebno je u postupanju osigurati adekvatan tretman izbjeglica, odnosno omogućiti im pristup sustavu azila. Pritom se presretanjem smatra svaka mjera koju država upotrijebi kako bi spriječila ukrcavanje osoba na međunarodno putovanje, nastavak međunarodnog putovanja osoba koje su takvo putovanje već započele, odnosno kontrolu plovila ako postoji opravdana sumnja da prevozi osobe suprotno međunarodnom i pomorskom pravu (UNHCR, 2003). Drugim riječima, presretanje može biti fizičko ili »aktivno«, kao što je presretanje brodova na moru, i administrativno ili "pasivno«, kao primjerice putem viznog režima.

U odnosu na izbjeglice koje dolaze brodovima humanitarna je obveza obalnih država dozvoliti plovilima u nevolji da potraže utočište u njihovim teritorijalnim vodama, a osobama koje to žele da zatraže azil (UNHCR, 1979). Naime obalna država ima sudbenost nad brodom u neškodljivom prolasku njezinim teritorijalnim vodama: sudbenost uključuje i situaciju kada brod namjerava iskrcati putnike u suprotnosti s imigracijskim propisima dotične države. $U$ odnosu na strani brod u plovidbi vanjskim morskim pojasom obalna država ima ograničena prava nadzora i kažnjavanja samo ako postoji osnovana sumnja da je počinjeno ili da će se počiniti zabranjeno djelo na dijelu njezina kopnenog područja, unutrašnjih morskih voda, teritorijalnog mora i arhipelaških voda, uključujući djela protiv imigracijskih propisa. Na otvorenome moru presretanje je u načelu dozvoljeno samo u određenim slučajevima, između ostaloga ako postoji sumnja da se brod bavi piratstvom ili trgovinom robljem, da brod nema državnu pripadnost ili

V. npr. UNHCR (1993, 1994, 1997, 1998b, 1999, 2004). 
da je, iako je istaknuo stranu zastavu ili odbija istaknuti svoju zastavu, brod ustvari iste državne pripadnosti kao i (ratni) brod koji ga presreće (Konvencija o pravu mora, 1982: čl. 21, 33, 110). Izbjeglicama slijepim putnicima trebalo bi omogućiti, kad god je to moguće, iskrcavanje u prvoj luci kako bi se proveo postupak utvrđivanja izbjegličkog statusa (UNHCR, 1998a).

Pristup sustavu azila zajamčen je i pravnom stečevinom EU-a. Prema revidiranoj Direktivi o postupku, ${ }^{4}$ države članice EU-a obvezne su osigurati pristup postupku azila (čl. 6.). Pristup sustavu azila zajamčen je i Schengenskim acquisom, ${ }^{5}$ koji državama članicama nalaže obvezu primjene međunarodnih izbjegličkih konvencija te suradnju s UNHCR-om. Zakonik o schengenskim granicama ${ }^{6}$ primjenjuje se na svaku osobu koja prelazi unutarnje ili vanjske granice država članica Schengenskog prostora. Sukladan je temeljnim pravima i načelima iz Povelje Europske unije o temeljnim pravima (Charter of Fundamental Rights of the European Union, 2007) i treba se primjenjivati u skladu s obvezama država članica u odnosu na međunarodnu zaštitu. Pravna stečevina EU-a o azilu primjenjuje se od trenutka kada osoba stigne na granicu, uključujući teritorijalne vode i tranzitne zone (čl. 3. st. 1. Direktive o postupku).

U praksi međutim države na različite načine onemogućuju pristup svojem teritoriju, primjerice zatvaranjem granica, postavljanjem fizičkih barijera kojima se priječi ulazak u zemlju, restriktivnim viznim režimima, presretanjem na kopnu i moru, sankcioniranjem prijevoznika i pomagača te izvanteritorijalnim migracijskim kontrolama, čime dovode u pitanje prava zajamčena izbjeglicama Konvencijom iz 1951. Svrha tih mjera jest smanjiti broj tražitelja azila i zahtjeva za zaštitu, ušteda javnih sredstava, kriminalizacija migranata i odvraćanje od useljavanja te uvjeravanje biračkog tijela da se vlada može nositi s izbjegličkim problemom (Hassan, 2000: 184).

4 Directive 2013/32/EU of the European Parliament and of the Council of 26 June 2013 on common procedures for granting and withdrawing international protection, OJ L 180, 29. 06. 2013.

5 Schengenska pravna stečevina obuhvaća Schengenski sporazum iz 1985. (OJ L 239, 22. 09. 2000.) i Konvenciju o provedbi Schengenskog sporazuma iz 1990. (OJ L 239, 22. 09. 2000.) te deklaracije i odluke koje je usvojio Schengenski izvršni odbor.

6 Regulation (EC) No 562/2006 of the European Parliament and of the Council of 15 March 2006 establishing a Community Code on the rules governing the movement of persons across borders (Schengen Borders Code), OJ L 105, 13. 4. 2006., s izmjenama (OJ L 97, 09. 04. 2008.; OJ L 35, 04. 02. 2009.; OJ L 243, 15. 09. 2009.; OJ L 85, 31. 03. 2010.; OJ L 182, 29. 06. 2013.; OJ L 295, 06. 11. 2013.). 


\section{NAČELO ZABRANE VRAĆANJA U MEĐUNARODNOME IZBJEGLIČKOM PRAVU I PRAVNOJ STEČEVINI EU-A}

Načelo zabrane vraćanja (non-refoulement) temeljna je komponenta međunarodnopravne zaštite izbjeglica. Kodificirano je u čl. 33. st. 1. Konvencije iz 1951., a obuhvaća zabranu protjerivanja, vraćanja ili drugog oblika prebacivanja izbjeglica na teritorij na kojem bi njihov život ili sloboda bili izravno ugroženi zbog rasnih, vjerskih i nacionalnih razloga, kao i zbog pripadnosti određenoj društvenoj grupi ili zbog političkog mišljenja, odnosno na teritorij na kojem im prijeti daljnje protjerivanje, vraćanje ili prebacivanje na drugo područje gdje postoji takav rizik. Iznimno, od zabrane protjerivanja ili vraćanja izuzete su izbjeglice koje se opravdano smatra opasnima za sigurnost zemlje u kojoj se nalaze ili koje, nakon što su pravomoćno osuđene za posebno težak zločin, predstavljaju opasnost za društvo te zemlje (čl. 31. st. 2.).

Vraćanje (refoulement) je zabranjeno i drugim međunarodnim dokumentima, ${ }^{7}$ kao i sporazumima kojima se zabranjuje ako protjerivanjem ili vraćanjem osobi prijeti mučenje, okrutno, nečovječno ili ponižavajuće postupanje ili kažnjavanje.

Smatra se da zabrana vraćanja (non-refoulement) zbog svoje važnosti predstavlja dio međunarodnoga običajnog prava. No u literaturi ne postoji opće prihvaćanje zabrane vraćanja kao načela općega običajnog međunarodnog prava. Tako zabranu vraćanja kao dio običajnog prava navode Andrassy, Bakotić i Vukas (1995: 288), Lauterpacht i Bethlehem (2003: 149) i Goodwin-Gill (1996: 167-170). S druge strane, Lapaš (2008: 33) i Hathaway (2005: 363-370) smatraju kako se ne može tvrditi da je riječ o općemu običajnome međunarodnom pravu jer veliki broj država u praksi ne poštuje načelo zabrane vraćanja. Lapaš međutim dozvoljava da je u običajno pravo obveza na zabranu vraćanja ušla barem u pogledu pravno prisutnih izbjeglica i onih s dopuštenim boravkom, odnosno tražitelja azila (dalje: TA) koji legalno borave na teritoriju zemlje primateljice i priznatih izbjeglica, ali ne i za TA u nezakonitom boravku ili izbjeglice u odnosu puke jurisdikcije. ${ }^{8}$

\footnotetext{
Vraćanje je zabranjeno čl. 3. Deklaracije o teritorijalnom azilu iz 1967., čl. II. st. 3. Afričke konvencije o posebnim aspektima izbjegličkih problema (UNTS 1001, 10. 09. 1969.), čl. 22. st. 8. Američke konvencije o ljudskim pravima (UNTS 1144, 22. 11. 1969.) te dijelom III., para. 5. Kartagenske deklaracije o izbjeglicama (OAS Doc. OEA/Ser.L/V/II.66/doc.10, rev. 1, 22. 11. 1984.).

8 U smislu Konvencije iz 1951. moguće je razlikovati: a) odnos puke nadležnosti države, bez fizičke prisutnosti osobe na njezinu području (npr. u određenim slučajevima vršenje jurisdikcije države na otvorenome moru ili na području druge države, na svojim granicama i u međunarodnim zonama u zračnim lukama); b) odnos fizičke (de facto) prisutnosti
} 
Hailbronner (1989, prema Chimni, 2000: 111) navodi da je načelo zabrane vraćanja opće običajno pravo u nastajanju, odnosno regionalno običajno pravo u zapadnoj Europi, na američkom kontinentu i u Africi. I GoodwinGill (1996: 169) navodi da države nisu u potpunosti slobodne zanemariti načelo zabrane vraćanja, a ograničenost $\mathrm{u}$ diskreciji proizlazi iz međunarodnopravne definicije izbjeglice s jedne strane i općeg priznanja načela zabrane vraćanja s druge. UNHCR (1982) pak smatra kako je »načelo zabrane vraćanja (...) postupno zadobilo obilježje apsolutno obvezatnog pravila u međunarodnom pravu«.

No svi međunarodni dokumenti samo općenito zabranjuju vraćanje, bez jasna određivanja značenja pojedinih elemenata pojma, te ostavljaju tumačenje sadržaja zabrane vraćanja nacionalnim vlastima, sudovima i međunarodnim organizacijama (Pirjola, 2007: 658). Stoga je za provedbu načela zabrane vraćanja potrebno razmotriti činjenice svakoga pojedinog slučaja (Lauterpacht i Bethlehem, 2003: 150).

Temeljni standardi u tumačenju načela zabrane vraćanja uključuju sljedeće:

- Zabrana vraćanja odnosi se na priznate izbjeglice ali i na TA, a načelo zabrane vraćanja jedno je od temeljnih prava iz Konvencije iz 1951. zajamčenih izbjeglicama bez obzira na stupanj veze s državom primateljicom.

- Zabrana vraćanja primjenjuje se od trenutka kada osoba izrazi namjeru za traženje azila, odnosno za ulazak na teritorij države. U tom smislu zabrana vraćanja obuhvaća i zabranu vraćanja i zabranu odbijanja ulaska (Goodwin-Gill, 1996: 124).

- Načelo zabrane vraćanja odnosi se na izbjeglice i TA koji su fizički (de facto) prisutni na području države prihvata, bez obzira na to borave li u državi zakonito ili ne (Grahl-Madsen, 1997 [1967]: 135).

- Pojam »države ugovornice« treba tumačiti na način da uključuje i državne i regionalne javne vlasti kao i sva ostala tijela i pravne osobe (primjerice prijevoznici koji obavljaju pregled putnih isprava u zem-

(TA i izbjeglice koji se nezakonito nalaze na području države prihvata, a da svoj ulazak i prisutnost nisu prijavili njezinim tijelima javne vlasti); c) odnos pravne (de iure) prisutnosti (TA i izbjeglice koji legalno borave na području države prihvata, bilo da su legalno ušli u državu, bilo da su svoj neregularni ulazak opravdali nadležnim tijelima); d) odnos dopuštenog boravka (izbjeglica kojoj je odobrena zaštita) (Lapaš, 2008: 9-18; Hathaway, 2005: 156-192). Sustav međunarodnopravne zaštite izbjeglica strukturiran je »slojevito«, pa svaki viši stupanj veze izbjeglice s državom prihvata uključuje i niže stupnjeve (Lapaš, 2008: 44). 
ljama polazišta ili tranzita) koji primjenjuju javne ovlasti određene države (Lauterpacht i Bethlehem, 2003: 108), pa i izvan njezina državnog područja (Lapaš, 2008: 34; Hathaway, 2005: 163), na graničnim prijelazima ili drugim točkama ulaska u zemlju, u međunarodnim zonama, na tranzitnim točkama i dr. Područje jurisdikcije određene države, uz njezin teritorij, uključuje i svako drugo područje nad kojim ima nadzor.

- Ako je riječ o TA ili izbjeglici čije izručenje traži druga država, potrebno je voditi računa o eventualnim posebnim potrebama zaštite takve osobe.

- Nadležna tijela (imigracijska ili ona granične policije) trebaju imati jasne upute što učiniti u slučaju traženja azila na granici, uključujući zračne luke, a u skladu s relevantnim međunarodnim instrumentima. Ulogu djelatnika granične policije treba ograničiti na osiguravanje neometanog pristupa TA postupku azila i sprečavanje vraćanja (UNHCR, 1977).

Načelo zabrane vraćanja zaštićeno je i pravnom stečevinom EU-a o azilu. Prema čl. 19. Povelje o temeljnim pravima, zabranjeno je vraćanje osobe u situaciju gdje ima osnovani strah od progona ili postoji stvaran rizik od mučenja ili neljudskog i ponižavajućeg postupanja ili kažnjavanja. Člankom 19. Povelje zabranjuje se kolektivno protjerivanje (stavak 1.) te se određuje kako nitko ne može biti udaljen, prognan ili izručen državi u kojoj bi bio izložen smrtnoj kazni, mučenju ili drugim neljudskim ili ponižavajućim postupcima i kaznama (stavak 2.). U Objašnjenju Povelje navodi se kako čl. 19. st. 2. obuhvaća relevantnu sudsku praksu ESLJP-a u svezi s clankom 3. EKLJP-a. ${ }^{9}$

Načelo zabrane vraćanja zaštićeno je i revidiranom Direktivom o kvalifikaciji, ${ }^{10}$ međutim ne u apsolutnom smislu. Naime člancima 17. i 21. dopušta se udaljenje izbjeglice $\mathrm{u}$ iznimnim okolnostima, primjerice kada osoba predstavlja opasnost za sigurnost države domaćina ili kada nakon počinjenja teškoga kaznenog djela osoba predstavlja opasnost za zajednicu. U takvim slučajevima država članica može opozvati, poništiti ili odbiti obnoviti ili izdati dozvolu boravka izbjeglici. Prema revidiranoj Direktivi

Vidi posebno: Explanations relating to the Charter of Fundamental Rights, OJ C 303, 14. 12. 2007.

10 Directive 2011/95/EU of the European Parliament and of the Council of 13 December 2011 on standards for the qualification of third-country nationals or stateless persons as beneficiaries of international protection, for a uniform status for refugees or for persons eligible for subsidiary protection, and for the content of protection granted (recast), OJ L 337, 20. 12. 2011. 
o postupku, neka država smatrat će se prvom državom azila tražitelju ako mu je u toj zemlji priznat status izbjeglice na koji se može pozvati ili ako na drugi način uživa dostatnu zaštitu u toj zemlji, što uključuje i načelo zabrane vraćanja (čl. 35.). Zabranu vraćanja države članice trebaju uzeti u obzir i ako odluče primijeniti koncept europske sigurne treće zemlje (čl. 39.).

Svaki oblik vraćanja na temelju Direktive o povratku ${ }^{11}$ ili premještaj u drugu državu članicu EU-a na temelju Dublinske uredbe ${ }^{12}$ moraju biti u skladu s pravom na azil i načelom zabrane vraćanja. U primjeni Zakonika o schengenskim granicama treba voditi računa o zaštiti načela zabrane vraćanja (preambula, tč. 20.). Tijekom provedbe aktivnosti upravljanja granicom mora se poštovati načelo neodbijanja prihvata (čl. 12. čitan zajedno s čl. 3. i 3a).

\section{ZABRANA VRAĆANJA U PRAKSI EUROPSKOG SUDA ZA LJUDSKA PRAVA}

Važan mehanizam za zaštitu TA i izbjeglica na području Europe predstavlja EKLJP. Iako se u Konvenciji pravo na azil ne spominje eksplicitno, kroz praksu ESLJP-a uspostavljen je niz standarda u zaštiti tražitelja azila, osobito u odnosu na vraćanje $\mathrm{e}^{13}$ osoba kojima prijeti mučenje ili drugo nečovječno postupanje ili kažnjavanje.

Iako EKLJP nije međunarodni instrument za zaštitu izbjeglica per se, niti eksplicite predviđa zabranu vraćanja, zabrana mučenja i nečovječnog ili ponižavajućeg postupanja ili kažnjavanja iz čl. 3., promatrana u svjetlu čl. 1., prema kojem obveze zaštite prava i sloboda postoje u odnosu na sve osobe pod jurisdikcijom pojedine zemlje, zajamčena je kako državljanima tako i osobama koje legalno borave na njezinu teritoriju, uključujući i TA, ali i osobama u neregularnom boravku.

Prema tumačenju ESLJP-a, snaga i važnost čl. 3. proizlaze iz činjenice da se njime štiti jedna od temeljnih vrijednosti demokratskih društava država članica Vijeća Europe.

11 Directive 2008/115/EC of the European Parliament and of the Council of 16 December 2008 on common standards and procedures in Member States for returning illegally staying third-country nationals, OJ L 348, 24. 12. 2008.

12 Regulation (EU) No 604/2013 of the European Parliament and of the Council of 26 June 2013 establishing the criteria and mechanisms for determining the Member State responsible for examining an application for international protection lodged in one of the Member States by a third-country national or a stateless person, OJ L 180, 29. 06. 2013.

13 Ovdje se termin »vraćanje« upotrebljava kao generički pojam koji obuhvaća izručenje, prisilno udaljenje i protjerivanje. 
Zabrana vraćanja prvi je put razmatrana 1989. u predmetu Soering protiv Ujedinjenoga Kraljevstva (1989: para. 88), u kojem je ESLJP ${ }^{14}$ zauzeo stav da bi se vraćanje osobe u državu u kojoj joj prijeti izvršenje smrtne kazne smatralo povredom čl. 3. Već dvije godine poslije ta zabrana počela se razmatrati i u odnosu na odbijene TA (Cruz Varas i ostali protiv Švedske, 1991). Prema ESLJP-u, »vraćanje tražitelja azila može dovesti do kršenja članka 3. i posljedično do odgovornosti države članice prema Konvenciji ako postoje utemeljeni razlozi za vjerovanje da za osobu, ako je država protjera, postoji opravdan rizik da će po povratku u zemlju izručenja biti izložena mučenju ili nečovječnom postupanju ili kažnjavanju « (Vilvarajah i drugi protiv Velike Britanije, 1991: para. 103). Danas je primjenjivost čl. 3. u slučajevima vraćanja »ustanovljena izvan svake sumnje« (Mole, 2007: 20).

\section{Odgovornost i jurisdikcija države u odnosu na članak 3. Europske konvencije}

Premda je ESLJP u više presuda naglasio kako države članice imaju pravo kontrole ulaska, boravka i protjerivanja stranih državljana, utemeljeno na međunarodnom pravu, također navodi da »u slučaju kada jedna država članica vrati stranog državljanina, može doći do kršenja čl. 3. ako se utvrdi da bi vraćanje određene osobe dovelo do stvarne opasnosti da ta osoba bude podvrgnuta postupanju koje je u suprotnosti s čl. 3. u zemlji primateljici« (Ahmed protiv Austrije, 1996: para. 38 i 39).

Pristup teritoriju za one koji nisu državljani nije izrijekom reguliran EKLJP-om niti se utvrđuje tko bi trebao dobiti dozvolu ulaska (vizu). No sudska praksa ESLJP-a nameće određena ograničenja na pravo država da odbiju nekoga sa svojih granica, primjerice kada bi to rezultiralo odbijanjem prihvata, a u određenim slučajevima može se zahtijevati od države dozvola ulaska određenoj osobi kad je to preduvjet za ostvarivanje nekih konvencijskih prava. Zabranjeno je odbiti ulaz osobi, bilo na granici, bilo drugdje unutar jurisdikcije države, i izložiti je riziku mučenja ili neljudskog ili ponižavajućeg postupanja ili kažnjavanja.

Države članice odgovornost prema čl. 3. imaju za sve posljedice vraćanja koje mogu nastati u području izvan njihove jurisdikcije, a ta odgovornost isključivo leži na državi koja vraća osobu, ne i na državi primateljici (Soering

14 Do stupanja na snagu Protokola br. 11. o preinaci kontrolnog mehanizma ustanovljenoga Konvencijom 1998., nadzor nad primjenom Europske konvencije provodila su dva tijela: Europska komisija za ljudska prava i ESLJP. Stupanjem na snagu Protokola br. 14. u lipnju 2010. nadzorni je sustav izmijenjen. Ovdje se termin ESLJP upotrebljava i u odnosu na odluke Europske komisije za ljudska prava. 
protiv Ujedinjenoga Kraljevstva, 1989: para. 86 i 91). Odgovornost države u odnosu na čl. 3. postoji i u slučaju vraćanja u zemlju u kojoj osobi ne prijeti opasnost od mučenja ili nečovječnog postupanja ili kažnjavanja, ali iz koje bi mogla biti udaljena u zemlju u kojoj takav rizik postoji (T. I. protiv Velike Britanije, 2000).

Što se tiče pristupa sustavu azila i mjera kojima države kontroliraju pristup svom teritoriju, ESLJP je u odnosu na viznu politiku zauzeo stav da su vlasti države ugovornice odgovorne ratione loci Sudu u pogledu odluka o (ne)odobravanju viza kojima se krše prava zaštićena EKLJP-om (Mole, 2007: 63).

Osobe se mogu nalaziti pod jurisdikcijom države i ako se nalaze na otvorenome moru, ako država nad njima ima nadzor, a odgurivanje na otvorenome moru može predstavljati kršenje načela zabrane vraćanja. Takav je stav ESLJP zauzeo u predmetu Hirsi Jamaa i ostali protiv Italije (2012), u kojem je bila riječ o skupini od oko dvjesto migranata koju je talijanska obalna straža presrela na otvorenome moru i po kratkom postupku vratila u Libiju. Migrantima nije dana mogućnost da zatraže azil niti su registrirani. ESLJP je smatrao da su talijanske vlasti znale, ili su trebale znati, da će migranti nakon vraćanja u Libiju, zbog njezine prakse prema neregularnim migrantima i nepostojanja sustava azila, biti izloženi postupanju suprotnom pravima zajamčenim EKLJP-om te da im neće biti pružena nikakva zaštita, kao i da postoji mogućnost od lančanog vraćanja. Iako podnositelji zahtjeva nisu pred talijanskim vlastima zatražili azil ni opisali opasnost s kojom se suočavaju zbog nepostojanja sustava azila u Libiji, to ne izuzima Italiju od izvršavanja obveza prema čl. 3. Stoga su se talijanske vlasti trebale uvjeriti kako Libija ispunjava svoje obveze koje proizlaze iz međunarodnoga izbjegličkog prava. Vraćanje u Libiju predstavljalo je kršenje odredbi cl. 3. jer su se time tužitelji izložili riziku odbijanja prihvata.

U odnosu na prihvat tražitelja azila u tranzitnim zonama odgovornost države prema čl. 3. EKLJP-a postoji bez obzira na to smatra li država da se osoba zapravo ne nalazi na njezinu teritoriju (Amuur protiv Francuske, 1996). ${ }^{15}$

Pitanje nacionalnih politika prihvata u kontekstu čl. 3. razmatrano je u dvije situacije (Lambert, 2005: 42). Prva se odnosi na već spomenute slučajeve lančanog vraćanja tražitelja azila u kojima je ESLJP zauzeo stav da takvo

15 U tom predmetu tužitelji su zadržani u tranzitnoj zoni pariške zračne luke, a francuske su vlasti tvrdile da nisu »ušli « $\mathrm{u}$ Francusku te da nisu pod njezinom jurisdikcijom. ESLJP je zauzeo stav da su odredbe nacionalnog prava na snazi u to vrijeme nedovoljno jamčile zaštitu prava tužitelja na slobodu u skladu s čl. 5. st. 1. te da postoji jurisdikcija Francuske u tranzitnoj zoni. 
vraćanje u zemlje koje odbijaju preuzeti odgovornost za osobu može dovesti do nečovječnog postupanja. Druga situacija uključuje zabranu diskriminatornog postupanja iz čl. 14. EKLJP-a, u kojoj je ESLJP zauzeo stav kako takvo postupanje može pod određenim pretpostavkama biti toliko ozbiljno da predstavlja mučenje ili nečovječno postupanje ili kažnjavanje. ${ }^{16}$

Prema judikaturi ESLJP-a u odnosu na grupno protjerivanje stranaca iz čl. 4. Protokola br. 4, protjerivanje se može smatrati kolektivnim ako svaki pojedinačni slučaj nije individualno i objektivno ispitan i razmotren. U slučaju Hirsi Jamaa $i$ drugi protiv Italije (2012) talijanske su vlasti pri provedbi »odgurivanja« broda s potencijalnim TA prekršile čl. 4. Protokola br. 4., a ESLJP je smatrao da se zabrana protjerivanja treba primjenjivati i na mjere na otvorenome moru.

\section{Priroda rizika od zlostavljanja}

ESLJP, premda je identificirao elemente po kojima se postupanje ili kažnjavanje kvalificira kao mučenje, nije definirao značenje samog pojma, već je u određenom dijelu podržao definiciju iz Konvencije o sprečavanju mučenja i drugoga okrutnog, nečovječnog ili ponižavajućeg postupanja ili kažnjavanja. ${ }^{17}$ Tako u Grčkom slučaju (1969) ESLJP pojam mučenja i nečovječnog postupanja ili kažnjavanja opisuje ovako: »nečovječno ili degradirajuće postupanje ili kažnjavanje odnosi se barem na postupanje kojim se namjerno uzrokuje psihička ili fizička patnja, neopravdana u danoj situaciji «. Riječ mučenje često se upotrebljava za opisivanje nečovječnog postupanja u određenu svrhu poput prikupljanja informacija ili priznanja i izricanja kazne te se općenito može smatrati težim oblikom takva postupanja. Postupanje ili kažnjavanje može se smatrati degradirajućim ako teže ponižava pojedinca pred drugima ili dovodi do postupanja protivno njegovoj volji ili savjesti (Grčki slučaj, 1969). Podrobnije, da bi se određeno postupanje smatralo mučenjem, osim dosegnutoga određenog intenziteta mora biti dokazano da je zlostavljanje bilo namjerno, u svrhu postizanja određenog cilja ili izazivanja patnje. Primjeri zlostavljanja koji, prema praksi ESLJP-a, predstavljaju mučenje uključuju: »palestinsko vješanje«, električne šokove, batinanje, prijetnje smrću i obitelji, seksualno zastrašivanje i ponižavanje, strah od pogu-

16 V. npr. predmet Azijci iz Istočne Afrike protiv Ujedinjenoga Kraljevstva, u kojem je ESLJP utvrdio da je imigracijski zakon koji je Azijcima, državljanima Velike Britanije nastanjenima u Istočnoj Africi, onemogućivao ulazak u Veliku Britaniju bio diskriminatorne prirode (INTERIGHTS, 2009: 37-38).

17 Konvencija o sprečavanju mučenja i drugoga okrutnog, nečovječnog ili ponižavajućeg postupanja ili kažnjavanja, UNTS 1465, 10. prosinca 1984., SL SFRJ:MU 9/9. 
bljenja, uvjeti pritvora, prisilno hranjenje posebno nasilnim i ponižavajućim postupcima, silovanje i prijetnje silovanjem (INTERIGHTS, 2009: 9-13).

U odnosu na kvalifikaciju djela mučenja i nečovječnog ili ponižavajućeg postupanja ili kažnjavanja "pretrpljeno zlostavljanje mora dosegnuti najnižu razinu okrutnosti da bi potpalo u doseg čl. 3. Ocjena ove najniže razine relativna je: ona ovisi o svim okolnostima predmeta, kao što su narav i kontekst postupanja prema žrtvi te njegovo trajanje, psihički i mentalni učinci i, u nekim slučajevima, spol, dob te zdravstveno stanje žrtve« (Cruz Varas $i$ ostali protiv Švedske, 1991: para. 83).

Mučenje i drugi oblici nečovječnog postupanja u načelu se razlikuju prema intenzitetu izazvane patnje. Nečovječno postupanje uključuje primjerice nasilje za vrijeme uhićenja ili pritvora, ozbiljnu medicinsku nepažnju za vrijeme pritvora i duševne boli (INTERIGHTS, 2009: 14-20). Tako je u predmetu D. protiv Velike Britanije (1997), u kojem je bila riječ o državljaninu Svetoga Kristofora i Nevisa koji je bolovao od AIDS-a, ESLJP zaključio da bi njegovo vraćanje u zemlju podrijetla u kojoj nema obitelj, materijalnih sredstava za život ni socijalnu pomoć niti postoji adekvatno liječenje AIDS-a i »vodeći računa o uznapredovalom stadiju njegove smrtonosne bolesti (...) predstavljalo nečovječno postupanje« (D. protiv Velike Britanije, 1997: para. 53). No u kasnijoj praksi ESLJP je proglasio nedopuštenim zahtjeve HIV-pozitivnih osoba koje su tvrdile da bi vraćanje u zemlje podrijetla predstavljalo kršenje čl. 3. ${ }^{18}$ Slično, u predmetu N. protiv Ujedinjenoga Kraljevstva (2008) ESLJP je zauzeo stav kako vraćanje u Ugandu ne bi predstavljalo kršenje čl. 3. jer su dostupni dokazi potvrdili kako je neki oblik liječničke skrbi dostupan u toj državi te da osoba nije smrtno bolesna. Moguće je stoga zaključiti kako ESLJP smatra da moraju biti kumulativno ispunjeni uvjeti nepostojanja adekvatnog liječenja u zemlji podrijetla i uznapredovalog stadija bolesti (Mole, 2007: 31).

Zabrana mučenja, odnosno vraćanja zbog rizika od zlostavljanja nije uvjetovana postojanjem određenih okolnosti na strani osobe (npr. rasa, vjera, ili drugi razlozi za kvalifikaciju izbjegličkog statusa) kao u Konvenciji iz 1951.

Kriterij za procjenu je li u konkretnom slučaju riječ o individualnoj prijetnji, odnosno stvarnom riziku, jest dokazan i relativno visok stupanj vjerojatnosti da osobi uistinu prijeti opasnost od zlostavljanja te nemogućnost vlasti odnosne države da joj pruže adekvatnu zaštitu. Pritom ESLJP u procjeni je li u konkretnom slučaju riječ o stvarnoj opasnosti od mučenja primjenjuje

18 V. npr. Ndangoya protiv Švedske, 2004. 
vrlo visoke standarde, tvrdeći da samo mogućnost zlostavljanja nije dovoljna, već okolnosti slučaja moraju biti tako iznimne prirode da se očekuje da će osoba biti izravno izložena zlostavljanju (INTERIGHTS, 2009: 47).

Rizik u slučaju povratka mora se učiniti vjerojatnim, a zaključak da tijela javne vlasti nisu u stanju pružiti adekvatnu zaštitu opravdati. Tako je u predmetu Ahmed protiv Austrije (1996), u kojem su austrijske vlasti namjeravale vratiti državljanina Somalije, ESLJP zauzeo stav da povratak nije moguć zbog nepostojanja tijela javne vlasti u Somaliji koja bi mu mogla pružiti zaštitu. Smatrat će se da adekvatna zaštita ne postoji i kada zlostavljanje dolazi od čimbenika za koje tijela javne vlasti ne snose izravnu, ali ni neizravnu odgovornost (D. protiv Velike Britanije, 1997: para. 49).

Što se tiče zaštite koju pruža država, u kontekstu čl. 2. ESLJP je ustvrdio kako obveza pružanja adekvatne zaštite uključuje pozitivnu obvezu tijela javne vlasti na poduzimanje preventivnih mjera zaštite osobe čiji je život $u$ opasnosti zbog kaznenih djela druge osobe. Takve mjere moraju biti razumne, odnosno ne stavljati nemoguć ili neproporcionalan teret na tijela javne vlasti. U tom smislu dovoljno je da podnositelj zahtjeva pokaže kako tijela javne vlasti nisu učinila sve ono što bi se razumno moglo očekivati da bi se izbjegla stvarna i neposredna opasnost za život za koju su ta tijela znala ili su trebala znati (Osman protiv Velike Britanije, 1998: para. 115-116).

U slučajevima u kojima je riječ o vraćanju u državu u kojoj vladaju nemiri ili građanski sukobi ESLJP smatra kako osoba mora biti izložena većoj opasnosti od zlostavljanja od pripadnika iste ili slične skupine u sličnim okolnostima. Ako u državi postoji opće nasilje, primjerice rat, to u pravilu neće predstavljati povredu čl. 3. No u recentnijoj praksi ESLJP je zauzeo stav da kad je opće nasilje dovoljno snažno, osoba neće morati dokazivati individualnu prijetnju, već kombinaciju osobnih okolnosti i rizika općeg nasilja te ustvrdio da bi se suprotnim postupanjem »zaštita zajamčena člankom 3. mogla učiniti iluzornom.« (Salah Sheekh protiv Nizozemske, 2007: para. 148).

Ipak, opće nasilje u državi kao takvo može predstavljati ograničenje za vraćanje svih osoba u tu državu. Takav je stav ESLJP prvi put zauzeo u predmetu NA. protiv Ujedinjenoga Kraljevstva (2008), u kojem je zaključio kako razina općeg nasilja u Šri Lanki nije dostatna za zabranu svih vraćanja u tu državu. U predmetu Sufi i Elmi protiv Ujedinjenoga Kraljevstoa (2011) ${ }^{19}$ ESLJP je zauzeo stav kako je opće nasilje u Mogadishuu u Somaliji dostatne razine i intenziteta te da predstavlja stvarnu ugroženost života ili osobe

19 U novijoj praksi ESLJP situaciju u Mogadishuu smatra boljom te odstupa od svog stava o zabrani vraćanja zbog općeg nasilja (v. K. A. B. protiv Švedske, 2013). 
svakog civila samo na temelju prisutnosti u državi, osim ako nije moguće dokazati kako je ta osoba dovoljno dobro povezana s gradskim moćnicima, što joj može omogućiti dobivanje zaštite.

$\mathrm{U}$ odnosu na mogućnost zaštite $\mathrm{u}$ određenom dijelu teritorija države $\mathrm{u}$ koju se osobu vraća ESLJP je u dosadašnjoj praksi uglavnom samo izvodio zaključak kako osoba ne može zatražiti zaštitu ni u jednom dijelu države vraćanja. ${ }^{20}$ No u recentnijoj praksi ESLJP je uputio i na određene pretpostavke koje je potrebno preispitati u odnosu na postojanje zaštite na određenom dijelu teritorija, uključujući mogućnost dolaska osobe na to područje te njezin prihvat i nastanjivanje (Salah Sheekh protiv Nizozemske, 2007: para. 141). Tako je u predmetu Sufi i Elmi protiv Ujedinjenoga Kraljevstva ESLJP zauzeo stav da je moguće kako u nekim dijelovima južne i središnje Somalije osobi ne bi nužno prijetio rizik od zlostavljanja isključivo zbog stanja opće opasnosti. Kada bi osobe morale putovati u područje pod nadzorom al-Shabaaba ili kroz njega, vrlo bi vjerojatno bile izložene riziku od postupanja protivnog čl. 3., osim ako se ne bi moglo dokazati da su nedavno boravile u Somaliji te bi zbog toga mogle izbjeći pozornost al-Shabaaba. ${ }^{21}$

Što se tiče počinitelja progona, ESLJP je zauzeo stav da opasnost od mučenja ili nečovječnog postupanja ili kažnjavanja »potječe i od osoba ili grupacija koje nisu tijela državne vlasti, međutim mora se dokazati da je rizik realan i da vlasti države u koju se osoba upućuje nisu u stanju spriječiti rizik osiguravanjem odgovarajuće zaštite« (H. L. R. protiv Francuske, 1997: para. 40).

Članak 3. EKLJP-a jamči širu zabranu vraćanja od one iz čl. 33. st. 2. Konvencije iz 1951., prema kojem su od zabrane vraćanja izuzete izbjeglice koje se opravdano smatra opasnima za sigurnost zemlje u kojoj se nalaze: ESLJP je kroz svoju praksu potvrdio da postojanje okolnosti za primjenu klauzula o izuzeću iz Konvencije iz 1951. ne ograničava primjenu čl. 3. EKLJP-a, čak ni u slučaju terorističkog djelovanja. ESLJP je prvi put razmatrao slučaj vraćanja osobe koju je država smatrala ozbiljnom prijetnjom nacionalnoj sigurnosti zbog međunarodnog terorizma u predmetu Chahal protiv Velike Britanije (2001), u kojem je zauzeo stav da bi vraćanje osobe koja je deklarirani Sikh separatist u Indiju, u kojoj joj prijeti stvarni rizik od mučenja ili nečovječnog postupanja ili kažnjavanja, predstavljalo kršenje čl. 3. Slično, u presudi Saadi protiv Italije (2008) ESLJP je zauzeo stajalište da nije mogu-

20 Tako je u predmetima Chahal protiv Velike Britanije (2001) i Hilal protiv Ujedinjenoga Kraljevstva (2001).

${ }^{21}$ U ovom predmetu ESLJP je smatrao da bi podnositelji zahtjeva bili izloženi stvarnom riziku postupanja protivnom čl. 3 . 
će procjenjivati rizik od zlostavljanja kojem se neka osoba izlaže u odnosu na potencijalnu opasnost koju ta osoba predstavlja za zajednicu ako ostane u državi prihvata: »očekivanje da bi tužitelj mogao predstavljati ozbiljnu prijetnju zajednici nipošto ne umanjuje postojanje ozbiljnog rizika da bi u slučaju vraćanja mogao pretrpjeti ozbiljnu štetu. « Što se tiče argumenta da bi, u slučajevima u kojima je riječ o pojedincima koji predstavljaju prijetnju nacionalnoj sigurnosti, postojanje takva rizika trebalo biti utvrđeno na temelju čvrstih dokaza, takav bi pristup bio protivan apsolutnoj prirodi čl. 3 . EKLJP-a: »Takvi argumenti samo potvrđuju da se pod opravdanjem zaštite nacionalne sigurnosti, u slučajevima u kojima ne postoje takvi čvrsti dokazi, pojedince izlaže riziku zlostavljanja.« (Saadi protiv Italije, 2008).

\section{ZAKLJUČAK}

Analiza provedena $\mathrm{u}$ ovom radu potvrdila je pretpostavku da je zabrana vraćanja kao temeljno načelo međunarodnoga (i europskoga) izbjegličkog prava neodvojivo povezana s omogućivanjem pristupa sustavu azila koje uključuje i pravo na pristup teritoriju zemlje utočišta. Kao dio svojih obveza u zaštiti ljudskih prava, države su dužne omogućiti ostvarenje prava na azil kako je ono definirano $\mathrm{u}$ temeljnim međunarodnim, europskim i domaćim pravnim aktima. Pravo na azil ne jamči dobivanje zaštite, no osigurava pristup pravičnom postupku utvrđivanja izbjegličkog statusa, a da bi se utvrdilo je li osobi potrebna međunarodna zaštita, nužno joj je omogućiti ulazak na teritorij države. U tom smislu ograničavanje pristupa sustavu azila onemogućuje provedbu postupka utvrđivanja izbjegličkog statusa, što znači da se neće utvrditi kojim osobama prijeti opasnost od proganjanja ili zlostavljanja ako im se ne dodijeli zaštita. Načelo zabrane vraćanja prevenira kršenja temeljnih ljudskih prava, pa je njegova bezuvjetna primjena od najveće važnosti.

Na međunarodnoj razini ne postoji neovisni međunarodni nadzorni mehanizam kojem bi države odgovarale za kršenje načela zabrane vraćanja jer je Konvencija iz 1951. jedan od samo dva međunarodna ugovora za zaštitu ljudskih prava kojim nije predviđen takav mehanizam. No njezine su odredbe, uključujući i načelo zabrane vraćanja, kodificirane u domaćim zakonodavstvima država potpisnica i pravnoj stečevini EU-a u mjeri koja je neusporediva s bilo kojim drugim međunarodnim ugovorom iz područja ljudskih prava (O'Byrne, 2013: 331-332). Stoga nadzor njezine provedbe osim na UNHCR-u leži i na regionalnim i domaćim sudovima. Iako ESLJP 
nije nadležan za odlučivanje o primjeni Konvencije iz 1951., kroz svoju je praksu de facto razmatrao određena pitanja povezana s pravima izbjeglica i razvio nove standarde zaštite, osobito u pogledu zabrane vraćanja.

Navedene međunarodne i europske standarde države moraju uzeti u obzir kada razmatraju uvođenje novih mjera za upravljanje migracijama preko svoga teritorija i na njemu.

\section{LITERATURA}

Andrassy, J., Bakotić, B. i Vukas, B. (1995). Međunarodno pravo, sv. I. Zagreb: Školska knjiga.

Chimni, B. S. (ur.) (2000). International Refugee Law: A Reader. New Delhi - Thousand Oaks - London: Sage Publications.

European Union Agency for Fundamental Rights - FRA (2015). Fundamental rights: challenges and achievements in 2014 - Annual report, http://fra.europa.eu/en/ publication/2015/fundamental-rights-challenges-and-achievements-2014 (30. 11. 2015.).

Goodwin-Gill, G. S. (1996). The Refugee in International Law. Oxford: Clarendon Press.

Grahl-Madsen, A. (1997 [1967]). Commentary of the Refugee Convention 1951 (Articles 2-11, 13-37). UNHCR, http://www.refworld.org/docid/4785ee9d2.html (01. 12. 2015.).

Hassan, L. (2000). Deterrence Measures and the Preservation of Asylum in the United Kingdom and the United States, Journal of Refugee Studies, 13 (2): 184-204, doi: 10.1093/jrs/13.2.184.

Hathaway, J. C. (2005). The Rights of Refugees under International Law. Cambridge: Cambridge University Press.

INTERIGHTS (2009). Manual for Lawyers: Article 3 of the European Convention of Human Rights, www.interights.org/document/104/index.html (01. 12. 2015.).

Lapaš, D. (2008). Međunarodnopravna zaštita izbjeglica. Zagreb: Hrvatski pravni centar.

Lambert, H. (2005). The European Convention on Human Rights and the Protection of Refugees: Limits and Opportunities, Refugee Survey Quarterly, 24 (2): 39-55, doi: 10.1093/rsq/hdi025.

Lauterpacht, E. i Bethlehem, D. (2003). The scope and content of the principle of nonrefoulement: Opinion, u: E. Feller, V. Türk i F. Nicholson (ur.). Refugee Protection in International Law: UNHCR's Global Consultations on International Protection. Cambridge: Cambridge University Press - UNHCR, 87-177, doi: 10.1017/cbo9780511493973.008.

Mole, N. (2007). Asylum and the European Convention on Human Rights. Strasbourg: Council of Europe.

O'Byrne, K. (2013). Is there a Need for Better Supervision of the Refugee Convention?, Journal of Refugee Studies, 26 (3): 330-359, doi: 10.1093/jrs/fet024.

Pirjola, J. (2007). Shadows in Paradise: Exploring Non-Refoulement as an Open Concept, International Journal of Refugee Law, 19 (4): 639-660, doi: 10.1093/ijrl/eem069. 


\section{DOKUMENTI I PROPISI}

Charter of Fundamental Rights of the European Union, OJ C 303, 14. 12. 2007., https://fra. europa.eu/sites/default/files/charter-of-fundamental-rights-of-the-european-union2007-c_303-01_en.pdf (30.11. 2015.).

Directive 2008/115/EC of the European Parliament and of the Council of 16 December 2008 on common standards and procedures in Member States for returning illegally staying third-country nationals, OJ L 348, 24. 12. 2008., http://eur-lex.europa.eu/legalcontent/EN/ALL/?uri=CELEX\%3A32008L0115 (01. 12. 2015.).

Directive 2011/95/EU of the European Parliament and of the Council of 13 December 2011 on standards for the qualification of third-country nationals or stateless persons as beneficiaries of international protection, for a uniform status for refugees or for persons eligible for subsidiary protection, and for the content of protection granted (recast), 20 December 2011, OJ L 337, 20. 12. 2011., http://www.refworld.org/ docid/4f197df02.html (30. 11. 2015.).

Directive 2013/32/EU of the European Parliament and of the Council of 26 June 2013 on common procedures for granting and withdrawing international protection, OJ L 180, 29. 06. 2013, http://eur-lex.europa.eu/legal-content/en/ ALL/?uri=celex\%3A32013L0032 (30. 11. 2015.).

Konvencija o pravu mora, UNTS 1833, 10. 12. 1982., NN:MU 11/95.

Konvencija o sprečavanju mučenja i drugoga okrutnog, nečovječnog ili ponižavajućeg postupanja ili kažnjavanja, UNTS 1465, 10. 12. 1984., SL SFRJ:MU 9/9.

Konvencija o statusu izbjeglica, UNTS 189, 28. 7. 1951., SL SFRJ: MU 15/1960.

Konvencija o zaštiti ljudskih prava i temeljnih sloboda, ETS 5, 4. 11. 1950., NN:MU 6/99, 9/99.

Regulation (EC) No 562/2006 of the European Parliament and of the Council of 15 March 2006 establishing a Community Code on the rules governing the movement of persons across borders (Schengen Borders Code), OJ L 105, 13. 04. 2006.; OJ L 97, 09.0 4. 2008.; OJ L 35, 04. 02. 2009.; OJ L 243, 15. 09. 2009.; OJ L 85, 31. 03. 2010.; OJ L 182, 29. 06. 2013.; OJ L 295, 06. 11. 2013, http://eur-lex.europa.eu/legal-content/EN/ ALL/?uri=celex\%3A32006R0562 (15. 11. 2015.).

Regulation (EU) No 604/2013 of the European Parliament and of the Council of 26 June 2013 establishing the criteria and mechanisms for determining the Member State responsible for examining an application for international protection lodged in one of the Member States by a third-country national or a stateless person, OJ L 180, 29. 06. 2013., http://eur-lex.europa.eu/legal-content/EN/ALL/?uri=celex\%3A32013R0604 (30. 11. 2015.).

The Schengen acquis - Convention implementing the Schengen Agreement of 14 June 1985, OJ L 239, 22. 09. 2000., http://eur-lex.europa.eu/legal-content/EN/ ALL/?uri=CELEX:42000A0922(02) (30. 11. 2015.).

UNHCR (1977). Determination of Refugee Status, No. 8 (XXVIII), http://www.unhcr. org/3ae68c6e4.html (30. 11. 2015.).

UNHCR (1979). Refugees without an Asylum Country, No. 15 (XXX), http://www.unhcr. org/3ae68c960.html (01. 12. 2015.).

UNHCR (1982). General Conclusion on International Protection, No. 25 (XXXIII), http:// www.unhcr.org/3ae68c434c.html (01. 12. 2015.). 
UNHCR (1993). General Conclusion on International Protection, No. 71 (XLIV), http:// www.unhcr.org/3ae68c6814.html (01. 12. 2015.).

UNHCR (1994). General Conclusion on International Protection, No. 74 (XLV), http:// www.unhcr.org/3ae68c6a4.html (01. 12. 2015.).

UNHCR (1997). Safeguarding Asylum, No. 82 (XLVIII), http://www.unhcr.org/3ae68c958. html_(30. 11. 2015.).

UNHCR (1998a). Stowaway Asylum-Seekers, No. 53 (XXXIX), http://www.unhcr. org/3ae68c4374.html (01. 12. 2015.).

UNHCR (1998b). Conclusion on International Protection, No. 85 (XLIX), http://www. unhcr.org/3ae68c6e30.html (30. 11. 2015.).

UNHCR (1999). General Conclusion on International Protection, No. 87 (L), http://www. unhcr.org/3ae68c6ec.html (30. 11. 2015.).

UNHCR (2003). Conclusion on Protection Safeguards in Interception Measures, No. 97 (LIV), http://www.unhcr.org/3f93b2894.html (30. 11. 2015.).

UNHCR (2004). Conclusion on International Cooperation and Burden and Responsibility Sharing in Mass Influx Situations, No. 100 (LV), http://www.unhcr.org/41751fd82. html (30. 11. 2015.).

UNHCR (2015). Syria Regional Refugee Response, http://data.unhcr.org/syrianrefugees/ regional.php (30. 11. 2015.).

\section{SLUČAJEVI}

Ahmed protiv Austrije (Ahmed v. Austria), zahtjev br. 25964/94, 17. 12. 1996.

Amuur protiv Francuske (Amuur v. France), zahtjev br. 19776/92, presuda 25. 06. 1996.

Chahal protiv Velike Britanije (Chahal v. United Kingdom), zahtjev br. 45276/99, presuda 08. 03. 2001.

Cruz Varas i ostali protiv Švedske (Cruz Varas and Others v. Sweden), zahtjev br. 15576/89, presuda 20. 03. 1991.

D. protiv Velike Britanije (D. v. The United Kingdom), zahtjev br. 30240/96, presuda 02. 05. 1997.

Grčki slučaj (The Greek Case), presuda 18. 11. 1969.

H. L. R. protiv Francuske (H.L.R. v. France), zahtjev br. 24573/94, presuda 29. 04. 1997.

Hilal protiv Ujedinjenoga Kraljevstva (Hilal v. The United Kingdom), zahtjev br. 45276/99, presuda 08. 03. 2001.

Hirsi Jamaa i ostali protiv Italije (Hirsi Jamaa and Others v. Italy), zahtjev br. 27765/09, presuda 23. 02. 2012.

K. A. B. protiv Švedske (K.A.B. v. Sweden), zahtjev br. 886/11, presuda 05. 09. 2013.

N. protiv Ujedinjenoga Kraljevstva (N. v. The United Kingdom), zahtjev br. 26565/05, presuda 27. 05. 2008.

NA. protiv Ujedinjenoga Kraljevstva (NA. v. The United Kingdom), zahtjev br. 25904/07, presuda 17. 07. 2008.

Ndangoya protiv Švedske (Ndangoya v. Sweden), zahtjev br. 17868/03, presuda 22. 06. 2004.

Osman protiv Velike Britanije (Osman v. The United Kingdom), zahtjev br. 23452/94, presuda 28. 10. 1998. 
Saadi protiv Italije (Saadi v. Italy), zahtjev br. 37201/06, presuda 28. 02. 2008

Salah Sheekh protiv Nizozemske (Salah Sheekh v. The Netherlands), zahtjev br. 1948/04, presuda 13. 01. 2007.

Soering protiv Ujedinjenoga Kraljevstva (Soering v. United Kingdom), zahtjev br. 14038/88, 07. 07. 1989.

Sufi i Elmi protiv Ujedinjenoga Kraljevstva (Sufi and Elmi v. the United Kingdom), zahtjev br. 8319/07 i 11449/07, presuda 28. 06. 2011.

T. I. protiv Velike Britanije (TI v. United Kingdom), zahtjev br. 43844/98, presuda 07. 03. 2000.

Vilvarajah i drugi protiv Velike Britanije (Vilvarajah and Others v. the United Kingdom), zahtjev br. 13163/87, 13164/87 i 13165/87, 30.10. 1991. 


\title{
The Principle of Non-Refoulement and Access to Asylum System: Two Sides of the Same Coin
}

\section{Goranka Lalić Novak}

\author{
SUMMARY
}

The European Union and other countries on the Balkan route for migrants have recorded a large increase in the number of asylum seekers. In parallel with the increased number of refugees trying to enter the territory of the EU, measures for migration management have tightened, and the right to asylum at the level of the Member States has been interpreted more and more restrictive. Search for protection from persecution has become a reason for closing borders and disabling access to territory and asylum system. However, access to asylum system is the first step in the realization of the right to asylum as guaranteed by international, European and national law. In addition to allowing access to territory and asylum system, which implies an obligation of states to accept refugees in order to confirm the need for international protection in a fair and efficient procedure, the states are obliged to respect the principle of non-refoulement. The aim of this paper is to clarify the connection between providing access to asylum system and respect for the principle of non-refoulement. Analysis in the paper was done by legal-dogmatic method of research and interpretation of legal acts and other authorities, as well as of UNHCR relevant recommendations and documents. The assumption is that without the provision of access to territory and asylum system the principle of non-refoulement cannot be respected. Apart from the international refugee law and doctrinal interpretations, it derives from the practice of the European Court of Human Rights regarding the prohibition of torture or other inhuman treatment or punishment guaranteed by the Convention for the Protection of Human Rights and Fundamental Freedoms. The conclusion is that the states must take into account international and European standards regarding the protection of the principle of non-refoulement when considering the introduction of new measures to manage migration movements.

KEY WORDS: right to asylum, non-refoulement, access to territory, European Court of Human Rights 